\title{
GROUND WATER CIRCULATION AND CHEMISTRY IN HYDROTOPES OF THE VISTULA VALLEY NEAR THE CITY OF PŁOCK
}

\section{INTRODUCTION}

In the paper the influence of the Vistula river valley on the ground water quality has been evaluated. The study area lays near the city of Plock, at the mouth of the Slupianka river. The method of terrain mapping units delination, called here - hydrotopes, has been used for selecting uniform parts of the valley. In every hydrotope the water and material fluxes have been considered, and how they influence the ground water chemistry.

Alluvial river valleys are important as a place where the ground and surface waters are mixing. Solid matter transport and deposition takes place in the alluvial sediments. The ground water can be enriched by the elements supplied by the atmospheric precipitation and/or river bank infiltration. The river valley sediments accumulate heavy metals, toxic organic compounds, and others.

Due to the interaction of the hydrological, biological, and geochemical processes, chemical elements stored in the sediments can be mobilized and reach saturation zone of the soil profiles. Flood plain sediments have a special function in this process, being some kind of buffer zone for the pollution.

Alluvial sediments lower the infiltration velocity, and also binds chemically some ions. The relief of the floodplain with numerous depressions also helps to retain the matter on its way to the river channel.

The main element of the alluvial valley system is the ground water. Fluctuation of the ground water table and its chemistry decide on many of the natural processes (Bajkiewicz-Grabowska, Mikulski, 1993). Usually, structure of the alluvial valley is complex, and consists of series of terraces. The circulation of water and solid matter in the terraces depends on their distance from the main river channel. Chemistry of the ground water is related to the aeration zone thickness, shallow ground water is more vulnerable to the pollution, while deeper ground water table guarantee more natural chemistry (Bajkiewicz-Grabowska, 1988). 


\section{DESCRIPTION OF THE STUDY AREA AND REGIONALIZATION METHODS}

Vistula river valley above the city of Plock is build in the Pleistocene and Holocene (Florek et. al, 1987). The width of the terraces varies from 3 $\mathrm{km}$ at the eastern bank of the Slupianka river (near Slupno village) to about $5 \mathrm{~km}$ (near Rydzyno village). Near Ośnica village the edge of Pleistocene plateau is located only $100-150 \mathrm{~m}$ from the bank of the Vistula River.

The youngest flood terrace (TH-4) along the Vistula river, has elevation only $2 \mathrm{~m}$ higher the mean annual river stage. The relief of this terrace is shaped only by the recent fluvial processes operating between the flood protective dikes.

Behind the flood protective dikes there is higher flood terrace (TH-3). Relief of this terrace has been modified by the catastrophic flood in 1924 . Recently it has elevation $2-5 \mathrm{~m}$ above the mean annual Vistula river stage. This terrace is build of Holocene alluvial sediments, namely sands of the channel face, and flood originated fine sediments. The depressions at the terrace TH-3 having depth $2-2.5 \mathrm{~m}$, are filled by the organic sediments.

The remaining two segments of the flood plain are two older terraces, TH-1 formed during Atlantic period, and TH-2 formed later. First can be found on both sides of the river, while second only on the western bank.

Holocene flood plain is enclosed by the three Pleistocene overflood terraces (Florek et. al, 1987): lowest (TP-2), higher (TP-1), and the highest (TP-0). On the higher Pleistocene overflood terrace (TP-1) there are sand dunes. Highest dune near the Liszyno village has the elevation of 7-7.5 m, and is 11,400 years old (Florek et. al, 1987).

Terrace TP-1 is merged with lower overflood terrace TP-2, this sequence is kind of anomaly in the alluvial valley structure. The surface of this terrace is intersected by the Slupianka river (the right tributary of the Vistula river). The highest terrace TP-0 lays at the edge of the Pleistocene plateau.

Generally, the system of the terraces declines toward the Vistula river. The higher Pleistocene terrace (TP-1) is the only exception, which together with the dune field, form watershed boundary between Slupianka and Vistula rivers (Fig. 1).

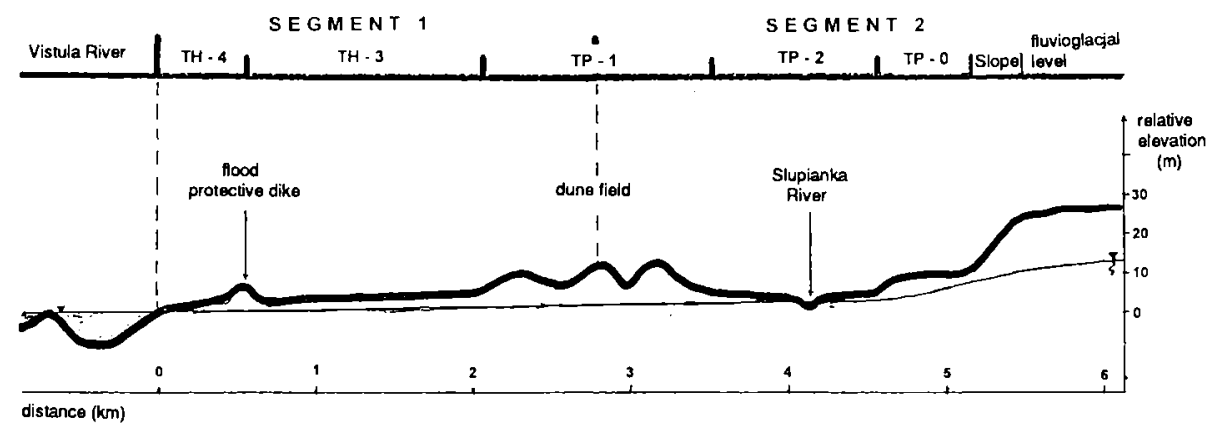

Fig. 1. Schematic cross section at the studied terraces 
The structure of the terraces makes unique conditions for the water circulation in every segment. The pattern of the water circulation in flood and overflood terraces is shown in the Figure 2. Alluvial waters in the flood terraces are in a hydraulic connection with the Vistula river, being at the same time fed by the ground water from higher terraces. During low stages the whole system is drained toward the Vistula river.

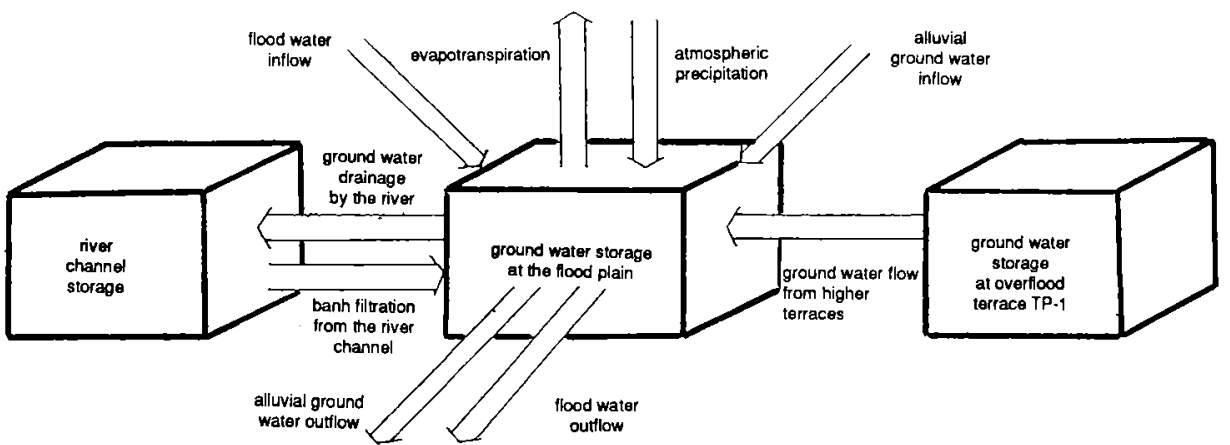

Fig. 2. Water circulation pattern at flood plain; terraces TH-3, TH-4

The next segment (Fig. 3) comprise the area from Słupianka river watershed boundary to the glacial plateau. The axe of this unit is Slupianka river channel, dissecting terrace TP-2. During the wet periods Słupianka river drains ground water, while during the drought its water supplies aquifer. Generally, the entire area is drained by the Vistula river.

To differentiate the hydrological conditions of the segments the so-called hydrotopes have been defined along the topographic profiles $500 \mathrm{~m}$ wide and $3-5 \mathrm{~km}$ long. The hydrotopes are terrain mapping units having similar type of water circulation (Richling, Ostaszewska, 1983). The components

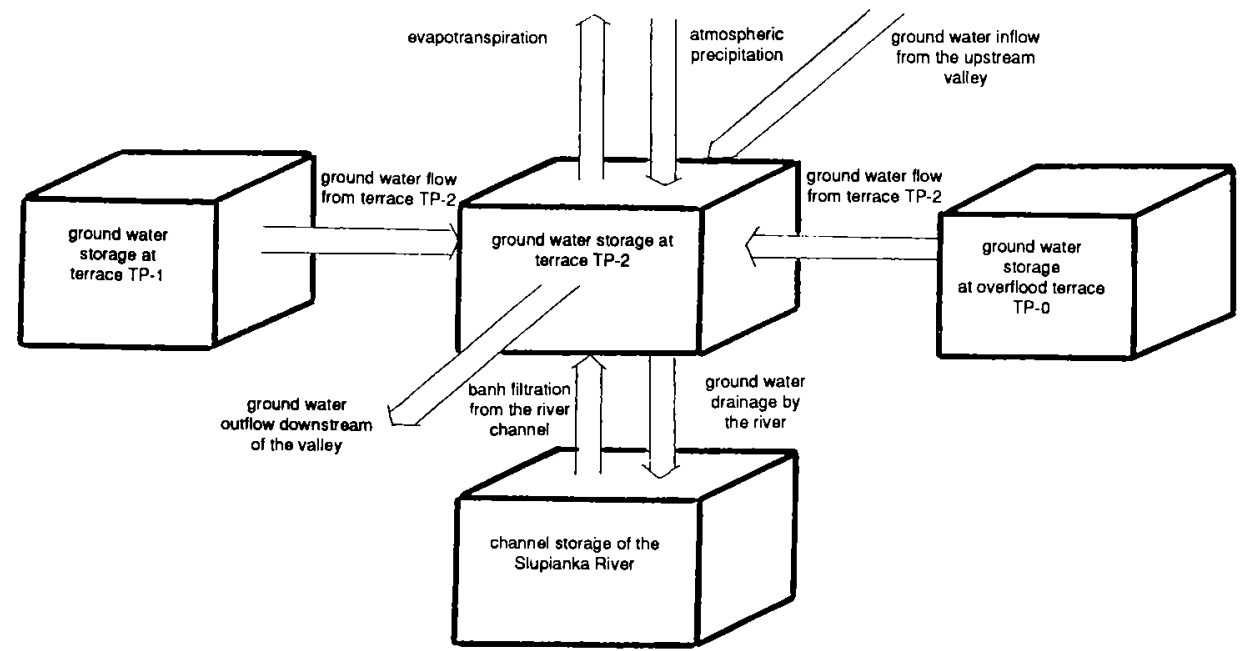

Fig. 3. Water circulation pattern at terrace TP-2 


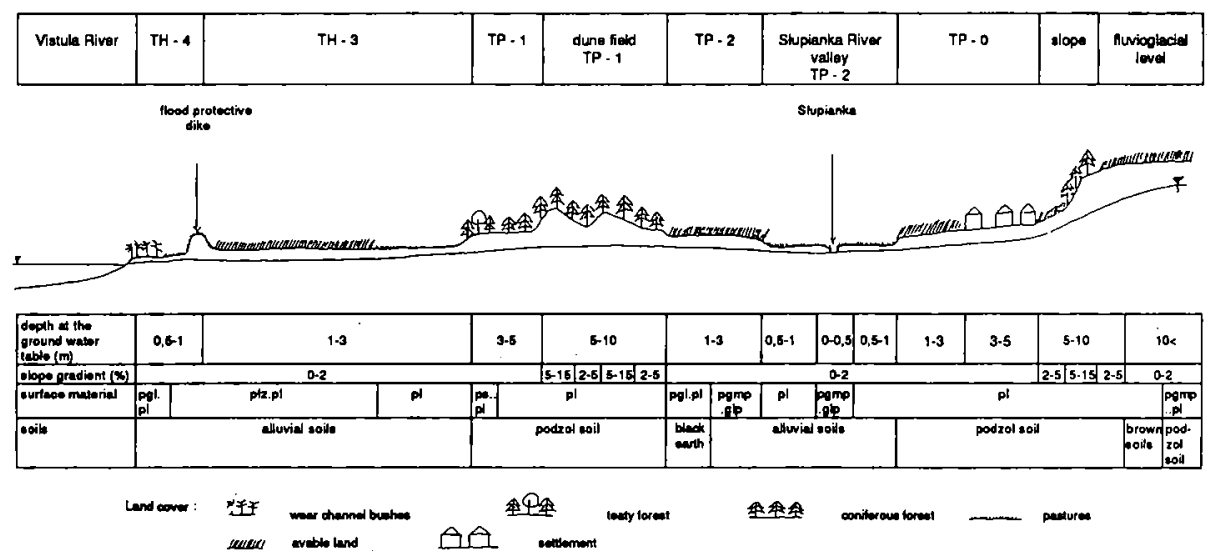

Fig. 4. The most common hydrotopes of the right side Vistula Valley near mouth of the Stupianka River

oof the hydrotopes like, geomorphology, soils, slopes, depth to the ground watcr, land use, have been digitized from maps in 1:10,000 scale, using ILWIS software. The most frequently occurring hydrotopes (Table 1 ) in a transect determine the type of water and solid matter circulation (Fig. 4).

\section{WATER AND SOLID MATTER CIRCULATION IN THE FLOOD PLAIN SEGMENTS}

Fluvioglacial terrace is located at the edge of the moraine plateau. It has a gentle slopes, deep aeration zone, and well permeable soils (Table 1). Soils have a low acid reaction, and small organic content which does not stop the migration of the chemical elements in infiltration process. Low reaction potential immobilizes only some compounds of iron, copper, and zinc. This segment belongs to the group of transeluvial landscapes, where ground water is chemically enriched, it has a relatively large content of calcium, potassium, sodium, and chloride (Table 2).

Slope of glaciofluvial terrace is build of sand deposits, has a steep slopes, deep aeration zone, and sparse vegetation cover (Table 1). It is a transit region for the ground water, so its chemistry does not change significantly.

Pleistocene highest terrace (TP-0) has rather uniform structure, good infiltration conditions, and shallow aeration zone. The acid reaction and small sorption capacity of the soils facilitate the solid matter migration to the ground water.

The ground water of this area has a low alkaline or acid reaction and increased mineralization. Deeper in the saturation zone we observe increase of the acid reaction and higher mineralization. Calcium ions content is doubled (Table 3). 
Table 1

Features of the main hydrotopes in the Vistula river valley near the city of Plock (symbols like on Fig. 1)

\begin{tabular}{|l|c|c|c|c|c|c|c|c|}
\hline \multicolumn{1}{|c|}{$\begin{array}{c}\text { Hydrotopes } \\
\text { features }\end{array}$} & \multicolumn{2}{|c|}{$\begin{array}{c}\text { Fluvioglacial } \\
\text { segrent }\end{array}$} & $\begin{array}{c}\text { Fluvioglacial } \\
\text { segrent slopes }\end{array}$ & \multicolumn{2}{c|}{$\begin{array}{c}\text { Overflood } \\
\text { terrace TP-0 }\end{array}$} & \multicolumn{2}{c|}{$\begin{array}{c}\text { Overflood } \\
\text { terrace TP-2 }\end{array}$} \\
\hline $\begin{array}{l}\text { Aeration zone } \\
\text { thicknes }\end{array}$ & $<10 \mathrm{~m}$ & $<10 \mathrm{~m}$ & $5-10 \mathrm{~m}$ & $5-10 \mathrm{~m}$ & $1-3 \mathrm{~m}$ & $1-3 \mathrm{~m}$ & $1-3 \mathrm{~m}$ & $1-3 \mathrm{~m}$ \\
\hline Slope gradients & $0-2 \%$ & $0-2 \%$ & $5-15 \%$ & $2-5 \%$ & $0-2 \%$ & $0-2 \%$ & $0-2 \%$ & $0-2 \%$ \\
\hline Surface material & $\mathrm{pl}(\mathrm{A}, \mathrm{Bw})$ & $\begin{array}{c}\mathrm{pggm} / \mathrm{pl} \\
(\mathrm{A})\end{array}$ & $\mathrm{pl}(\mathrm{A})$ & $\mathrm{pl}(\mathrm{A})$ & $\mathrm{pl}(\mathrm{A})$ & $\mathrm{pl}(\mathrm{A})$ & $\begin{array}{c}\mathrm{pgl} / \mathrm{pl} \\
(\mathrm{Dz})\end{array}$ & $\begin{array}{c}\mathrm{pgmp} / \mathrm{gl} \\
(\mathrm{F})\end{array}$ \\
\hline
\end{tabular}

\begin{tabular}{|l|c|c|c|c|c|c|c|c|}
\hline \multicolumn{1}{|c|}{$\begin{array}{c}\text { Hydrotopes } \\
\text { features }\end{array}$} & \multicolumn{2}{|c|}{$\begin{array}{c}\text { Slupianka river } \\
\text { valley }\end{array}$} & \multicolumn{2}{c|}{$\begin{array}{c}\text { Overflood } \\
\text { terrace TP-1 }\end{array}$} & \multicolumn{2}{c|}{$\begin{array}{c}\text { Dures } \\
\text { at overflood } \\
\text { terrace TP-2 }\end{array}$} & \multicolumn{2}{c|}{$\begin{array}{c}\text { Flood terrace } \\
\text { TH-3 }\end{array}$} \\
\hline $\begin{array}{l}\text { Aeration zone } \\
\text { thicknes }\end{array}$ & $0.5-1 \mathrm{~m}$ & $0-0.5 \mathrm{~m}$ & $3-5 \mathrm{~m}$ & $3-5 \mathrm{~m}$ & $5-10 \mathrm{~m}$ & $5-10 \mathrm{~m}$ & $1-3 \mathrm{~m}$ & $1-3 \mathrm{~m}$ \\
\hline Slope gradients & $0-2 \%$ & $0-2 \%$ & $0-2 \%$ & $0-2 \%$ & $5-15 \%$ & $0-2 \%$ & $0-2 \%$ & $0-2 \%$ \\
\hline Surface material & $\mathrm{pl}(\mathrm{F})$ & $\begin{array}{c}\mathrm{pgm} / \mathrm{pl} \\
(\mathrm{A})\end{array}$ & $\mathrm{pl}(\mathrm{A})$ & $\begin{array}{c}\mathrm{ps} / \mathrm{pl} \\
(\mathrm{A})\end{array}$ & $\mathrm{pl}(\mathrm{A})$ & $\mathrm{pl}(\mathrm{A})$ & $\mathrm{pl}(\mathrm{F})$ & $\mathrm{plz} / \mathrm{pl}(\mathrm{F})$ \\
\hline
\end{tabular}

\begin{tabular}{|l|c|c|}
\hline \multicolumn{1}{|c|}{$\begin{array}{c}\text { Hydrotopes } \\
\text { features }\end{array}$} & \multicolumn{2}{|l|}{ Flood terrace TH-4 } \\
\hline $\begin{array}{l}\text { Aeration zone } \\
\text { thicknes }\end{array}$ & $0.5-1 \mathrm{~m}$ & $0.5-1 \mathrm{~m}$ \\
\hline Slope gradients & $0-2 \%$ & $0-2 \%$ \\
\hline Surface material & $\mathrm{pg} \mathrm{V} / \mathrm{pl}(\mathrm{F})$ & $\mathrm{plz} / \mathrm{pl}(\mathrm{F})$ \\
\hline
\end{tabular}

Types of surface material: $\mathrm{pl}$ - loose sand; ps - slightly sand; pgl - light medium sand; pgmp - loamy sand; glp - light sandy loam; płz — very fine sandy soil

Types of soil: A - podzol soil; Bw - leached brown soil; $\mathrm{Dz}$ - degradated black earth; F - alluvial soil

Table 2

Ground water chemistry from Borowiczki-Parcele village spring at the fluvioglacial segment (February, 1992)

\begin{tabular}{|c|c|c|c|c|c|c|c|c|c|}
\hline$(\mathrm{pH})$ & $\begin{array}{c}\text { Total } \\
\text { hardness } \\
\left({ }^{\circ} \mathrm{N}\right)\end{array}$ & \multicolumn{10}{|c|}{$\mathrm{Ca}^{+2}$} & $\mathrm{Mg}^{+2}$ & $\mathrm{Na}^{+} \mathrm{K}^{+}$ & $\mathrm{CO}_{3}^{-2}$ & $\mathrm{HCO}_{3}^{-}$ & $\mathrm{Cl}^{-}$ & $\mathrm{SO}_{4}^{2}$ & $\begin{array}{c}\text { minera- } \\
\text { lization }\end{array}$ \\
\cline { 3 - 11 } & 15.8 & 109 & 1.8 & 24.1 & 0 & 251 & 35 & 77.3 & 499.4 \\
\hline 7.26 & 15 &
\end{tabular}

Table 3

Ground water chemistry at TP-0 terrace (February, 1992)

\begin{tabular}{|c|c|c|c|c|c|c|c|c|c|c|}
\hline \multirow{2}{*}{$\begin{array}{c}\text { Depth } \\
\text { (m) }\end{array}$} & \multirow[t]{2}{*}{$(\mathrm{pH})$} & \multirow{2}{*}{$\begin{array}{c}\text { Total } \\
\text { hardness } \\
\left({ }^{\circ} \mathrm{N}\right)\end{array}$} & \multicolumn{8}{|c|}{$\mathrm{mg} / \mathrm{l}$} \\
\hline & & & $\mathrm{Ca}^{+2}$ & $\mathbf{M g}^{+2}$ & $\mathrm{Na}^{+} \mathrm{K}^{+}$ & $\mathrm{CO}_{3}^{-2}$ & $\mathrm{HCO}_{3}^{-}$ & $\mathrm{Cr}$ & $\mathrm{so}_{4}^{2}$ & $\begin{array}{l}\text { minera- } \\
\text { lization }\end{array}$ \\
\hline $3.2 \mathrm{~m}$ & 7.25 & 9.4 & 59.4 & 5.5 & 86.2 & 0 & 263 & 42.5 & 77.7 & 534 \\
\hline $5.5 \mathrm{~m}$ & 7.44 & 16.1 & 106 & 5.5 & 38.0 & 0 & 293 & 35.4 & 77.5 & 556 \\
\hline
\end{tabular}

Pleistocene overflood terrace (TP-2) contains two types of hydrotopes (Table 1), agriculture is dominating in a land use. Infiltration conditions 
are different in both hydrotopes. The $\mathrm{pH}$ of the soils is around 6.9 , with weak alkaline reaction, the sorption potential of the soil is $5-7 \mathrm{me} / 100 \mathrm{~g}$, in such conditions only magnesium and manganese remain mobile. The ground water chemistry data is given in Table 4 . The ground water has a weak alkaline or neutral reaction, it has increased content of magnesium and manganese, as well as chloride. From heavy metals in the ground water only zinc and nickel have been detected. It can be noticed growing hardness of the deeper ground water layers, which is related to doubled concentration of the $\mathrm{Ca}+2$ ions. Generally due to the reaction and sorption properties terrace TP-2 has a predisposition to accumulate the pollution in the soils, and vegetation cover.

Slupianka river valley has the same type of hydrotopes like terrace TP-2, only ground water table is much more shallow (Table 1). The infiltration rate is good for the soils in this segment, but it does not mean that also the solid matter can migrate easily. Soil profiles shows gley layer which makes difficult to move such elements like zinc, nickel, copper, plumbum, cadmium. The main transport pattern of the many chemical elements is the river runoff (Table 5). Solid matter from hydrotops can extracted by the river draining ground water. In : ine river water heavy metals have been detected, with the cadmium concentration above the allowable level. Also high is the concentration of iron and ammonia nitrogen. The ground water has a neutral reaction, comparing to the ground water from higher terraces it has much lower calcium content, and higher sulphide concentration (Table 6).

Table 4

Ground water chemistry at TP-2 terrace (February, 1992)

\begin{tabular}{|c|c|c|c|c|c|c|c|c|c|c|}
\hline \multirow{2}{*}{$\begin{array}{c}\text { Depth } \\
\text { (m) }\end{array}$} & \multirow[t]{2}{*}{$(\mathrm{pH})$} & \multirow{2}{*}{$\begin{array}{c}\text { Total } \\
\text { hardness } \\
\left({ }^{\circ} \mathrm{N}\right)\end{array}$} & \multicolumn{8}{|c|}{$\mathrm{mg} / \mathrm{l}$} \\
\hline & & & $\mathrm{Ca}^{+2}$ & $\mathrm{Mg}^{+2}$ & $\mathrm{Na}^{+} \mathrm{K}^{+}$ & $\mathrm{CO}_{3}^{-2}$ & $\mathrm{HCO}_{3}^{-}$ & $\mathrm{Cr}^{-}$ & $\mathrm{SO}_{4}^{2}$ & $\begin{array}{l}\text { minera- } \\
\text { lization }\end{array}$ \\
\hline $3.2 \mathrm{~m}$ & 7.25 & 9.4 & 59.4 & 5.5 & 86.2 & 0 & 263 & 42.5 & 77.7 & 534 \\
\hline $5.5 \mathrm{~m}$ & 7.44 & 16.1 & 106 & 5.5 & 38.0 & 0 & 293 & 35.4 & 77.5 & 556 \\
\hline
\end{tabular}

Table 5

Słupianka river water chemistry at Słupno profile (after Płock Centre for Environmnent Studies and Control)

\begin{tabular}{|c|c|c|c|c|c|c|c|c|c|c|c|}
\hline Date & $\mathrm{pH}$ & \multicolumn{10}{|c|}{$\mathrm{mg} /$} \\
\cline { 2 - 9 } & $\mathrm{Mn}$ & $\mathrm{Pb}$ & $\mathrm{Cu}$ & $\mathrm{Ni}$ & $\mathrm{Cr}$ & $\mathrm{Zn}$ & $\mathrm{Cd}$ & sulphate & phoshate & chloride \\
\hline $12 . \mathrm{XI} .90$ & 7.9 & 0.03 & $\begin{array}{l}\text { not } \\
\text { de- } \\
\text { tected }\end{array}$ & $\begin{array}{l}\text { not } \\
\text { de- } \\
\text { tected }\end{array}$ & 0.09 & $\begin{array}{l}\text { not } \\
\text { de- } \\
\text { tected }\end{array}$ & 0.03 & $\begin{array}{l}\text { not } \\
\text { de- } \\
\text { tected }\end{array}$ & 77 & 0.17 & 28.5 \\
\hline $4 . \mathrm{XII.91}$ & 7.9 & 0.009 & $\begin{array}{l}\text { not } \\
\text { de- } \\
\text { tected }\end{array}$ & 0.035 & $\begin{array}{l}\text { not } \\
\text { de- } \\
\text { tected }\end{array}$ & $\begin{array}{l}\text { not } \\
\text { de- } \\
\text { tected }\end{array}$ & 0.01 & 0.028 & 84 & 0.35 & 36.0 \\
\hline
\end{tabular}


Ground water chemistry at Słupianka river valley (February, 1992)

\begin{tabular}{|c|c|c|c|c|c|c|c|c|}
\hline \multirow[t]{2}{*}{$(\mathrm{pH})$} & \multirow{2}{*}{$\begin{array}{c}\text { Total } \\
\text { hardness } \\
\left({ }^{\circ} \mathrm{N}\right)\end{array}$} & \multicolumn{7}{|c|}{$\mathrm{mg} / \mathrm{n}$} \\
\hline & & $\mathrm{Ca}^{+2}$ & $\mathrm{Mg}^{+2}$ & $\mathrm{Na}^{+} \mathbf{K}^{+}$ & $\mathrm{Fe}$ & Mn & $\mathrm{Cl}^{-}$ & $\mathrm{SO}_{4}^{2}$ \\
\hline 7.2 & 8.8 & 36.8 & 8.94 & 11.5 & 1.49 & $\begin{array}{l}\text { not de- } \\
\text { tected }\end{array}$ & 70.0 & 164 \\
\hline
\end{tabular}

Pleistocene overflood terrace TP-1 is located between Pleistocene overflood terrace TP-2 and Holocene flood terrace TH-3. It comprises two similar hydrotopes (Figure 4, Table 1). Podzol soils have developed on a sandy material. They have about $1.4 \%$ of organic matter, sorption $6.1 \mathrm{me} / 100 \mathrm{~g}$, and $6.2 \mathrm{pH}$. Loose sands are covered by pine forest, while silt sand by mixture forest. Both hydrotopes can infiltrate up to $30 \%$ of the annual precipitation. The properties of the hydrotopes result in a limited capability for accumulation of the chemical elements. The ground water of the terraces have neutral reaction, and total mineralization of $124 \mathrm{mg} /$ (Table 7). The mineralization is higher in the deeper parts of the aquifer. Comparing with the other terraces the ground water contains relatively small amounts of chloride, sulphide, and carbonates. Possibly these elements migrate to the less mobile ground waters of terraces TP-2 and TH-3. Increased concentration of the heavy metals has been detected, Ni up to $1.42 \mathrm{mg} /, \mathrm{Cd}-0.007 \mathrm{mg} /$, $\mathrm{Fe}-1,31 \mathrm{mg} / \mathrm{l}$ and $\mathrm{Mn}-0.62 \mathrm{mg} / \mathrm{l}$ (data after Plock Centre for Environment Studies and Control).

Table 7

Ground water chemistry at TP-1 terrace (February, 1992)

\begin{tabular}{|c|c|c|c|c|c|c|c|c|c|c|}
\hline \multirow{2}{*}{$\begin{array}{c}\text { Depth } \\
(\mathrm{m})\end{array}$} & $(\mathrm{pH})$ & \begin{tabular}{c} 
Total \\
hardness \\
\cline { 5 - 11 }
\end{tabular} & & \multicolumn{10}{|c|}{$\mathrm{N})$} & $\mathrm{Ca}^{+2}$ & $\mathrm{Mg}^{+2}$ & $\mathrm{Na}^{+} \mathrm{K}^{+}$ & $\mathrm{CO}_{3}^{-2}$ & $\mathrm{HCO}_{3}^{-}$ & $\mathrm{Cl}^{-}$ & $\mathrm{SO}^{2}$ & $\begin{array}{c}\text { mine- } \\
\text { ralizacja }\end{array}$ \\
\hline $3.0 \mathrm{~m}$ & 7.01 & 4.2 & 30.5 & 0 & 0.3 & 0 & 0.5 & 0.3 & 1.0 & 124.2 \\
\hline 6.1 & 7.38 & 12.5 & 88.3 & 0.07 & 1.3 & 0 & 4.0 & 0.5 & 1.3 & 445.5 \\
\hline
\end{tabular}

Dune field on the terrace TP-1 forms the watershed boundary of Słupianka river. It is build from loose sands, on which podzol soils have developed with organic matter content about $1 \%$, sorption $3.7 \mathrm{me} / 100 \mathrm{~g}$, and $4.9 \mathrm{pH}$. Vegetation cover is mostly pine forest, which highly reduce the surface runoff in this area. The ground water table is horizontal and rather deep (Table 1), the recharge is about $30 \%$ of the annual total precipitation. The ground water is drained toward overflood terrace TP-2 and flood terrace TH-3. This segment of the flood plain is autonomous and in limited degree can accumulate the chemical compounds, due to the prevailing acid reaction and small sorption of the soils. The ground water has a small mineralization and neutral reaction. 
Holocene flood terrace TH-3 consists of different materials on which alluvial soils have developed having up to $1.2 \%$ of the organic matter, sorption $6.2 \mathrm{me} / 100 \mathrm{~g}$, and $6.9 \mathrm{pH}$. Ground water table is shallow (Table 1). Relief of the landscape and type of the soils makes recharge ratio about $15 \%$ of the annual precipitation total. The ground water of the terrace has high mineralization (Table 8), high concentration of the sulphide, hydrocarbon, calcium, sodium, potassium ions. It has a neutral or weak alkaline reaction $(7.2-7.6 \mathrm{pH})$.

Holocene flood terrace TH-4 lays next to the Vistula river and has relatively uniform structure (Table 1). Prevailing are alluvial soils with the organic matter content $1.6 \%$, sorption $6 \mathrm{me} / 100 \mathrm{~g}$. Clay sands are covered by leafy forest, silt sand are used for pastures. The ground water table is shallow (Table 1) and in most cases drained by the Vistula river, but during the high stages of the river it can also be recharged by the bank filtration. This process may bring pollution from the surface water to the aquifer. The vertical movement of the chemical elements is limited by the gley layers in the soil profiles, their relatively high sorption potential, and neutral reaction.

Table 8

Ground water chemistry at TH-3 terrace (February, 1992)

\begin{tabular}{|c|c|c|c|c|c|c|c|c|c|c|}
\hline \multirow{2}{*}{$\begin{array}{c}\text { Depth } \\
(\mathrm{m})\end{array}$} & $(\mathrm{pH})$ & \begin{tabular}{c} 
Total \\
hardness \\
\cline { 4 - 12 }
\end{tabular} & & \multicolumn{10}{|c|}{$\mathrm{Ca}^{+2}$} & $\mathrm{Mg}^{+2}$ & $\mathrm{Na}^{+} \mathrm{K}^{+}$ & $\mathrm{CO}_{3}^{-2}$ & $\mathrm{HCO}_{3}^{-}$ & $\mathrm{Cl}^{-}$ & $\mathrm{SO}_{4}^{2}$ & $\begin{array}{c}\text { minera- } \\
\text { lization }\end{array}$ \\
\hline $2.2 \mathrm{~m}$ & 7.46 & 14.0 & 89.8 & 6.5 & 0 & 0 & 107.6 & 39.0 & 102 & 345.2 \\
\hline $4.4 \mathrm{~m}$ & 7.34 & 12.3 & 82.2 & 3.7 & 0 & 0 & 65.8 & 42.5 & 85.5 & 279.7 \\
\hline $6.0 \mathrm{~m}$ & 7.27 & 10.3 & 68.5 & 3.7 & 71.3 & 0 & 167.4 & 39.0 & 143 & 493.0 \\
\hline
\end{tabular}

\section{CONCLUSIONS}

The chemistry of the ground water from glacial plateau is partly transformed by alluvial valley of the Vistula river. Total mineralization increase mainly at the flood terraces, where higher concentration of sodium, potassium, sulphide, chloride ions is observed. The process of bank filtration can bee responsible for transformation of water quality in these aquifers. The ground water in terraces TP-1, and TP-2 has much lower mineralization than ground water form glacial plateau or flood terraces. We may assume that dense (high mineralization) ground water from glacial plateau flow beneath the ground water at the overflood terraces, and discharges at the flood terraces. At flood terraces ground water gets mixed with the river bank filtration water enriched by chloride and sulphide ions.

This processes cause the differentiation of the ground water quality in the alluvial valley. The area of the valley should not be treated as a uniform space, because on the relatively small distance between the edge of the valley and river significant changes in water quality takes place. 


\section{REFERENCES}

Bajkiewicz-Grabowska E., 1988, Ground water chemistry in the suburb area (a case study from Lomianki county). Prz. Geogr., t. LX, z. 1-2.

Bajki ewicz-Grabow ska E., Mikulski Z., 1993, Water and material fluxes in the alluvial river valley. Prz. Geofiz., t. XXXVIII, z. 1.

Florek E., Florek W., Mycielska-Dowgiałło E., 1987, Morphogenesis of the Vistula river valley between Kepa Polska and Płock in the late glacial and Holocene, in: Evolution of the Vistula river valley during last 15,000 years, part II. Geographical Studies, special issue no 1, IGiPZ.

Richling A., Ostaszewska K., 1983, From the metodology of delineation of the partial geocomplexes. Prz. Geogr., 55, z. 1. 
